RESEARCH PAPER

\title{
Educational inequalities in smoking among men and women aged 16 years and older in 11 European countries
}

\author{
M Huisman, A E Kunst, J P Mackenbach
}

Tobacco Control 2005;14:106-113. doi: 10.1136/tc.2004.008573

See end of article for authors' affiliations

Correspondence to:

Martijn Huisman,

Department of Public

Health, Erasmus MC,

University Medical Center

Rotterdam, PO Box 1738

3000 DR Rotterdam, The

Netherlands; m.huisman@ erasmusmc.nl

Received 15 April 2004

Accepted

2 November 2004 are at increased risk of smoking related diseases, we assessed

Objective: To determine those groups who are at increased risk of smoking related diseases, we assessed
in which male and female generations smoking was more prevalent among lower educated groups than in which male and female generations smoking was more

Design: Cross sectional analysis of data on smoking, covering the year 1998, from a social survey designed for all member states of the European Union.

Subjects: Higher and lower educated men and women aged 16 years and older from 11 member states of the European Union.

Outcome measures: Age standardised prevalence rates by education and prevalence odds ratios of current and ever daily smoking comparing lower educated groups with higher educated groups.

Results: A north-south gradient in educational inequalities in current and ever daily smoking was observed for women older than 24 years, showing larger inequalities in the northern countries. Such a gradient was not observed for men. A disadvantage for the lower educated in terms of smoking generally occurred later among women than among men. Indications of inequalities in smoking in the age group 16-24 years were observed for all countries, with the exception of women from Greece and Portugal.

Conclusions: Preventing and reducing smoking among lower educated subgroups should be a priority of policies aiming to reduce inequalities in health in Europe. If steps are not taken to control tobacco use among the lower educated groups specifically, inequalities in lung cancer and other smoking related diseases should be anticipated in all populations of the European Union, and both sexes.
$\mathrm{S}$ moking and smoking related diseases are important causes of socioeconomic inequalities in health. Among men in Western Europe, lung cancer is found to be the second largest contributor to educational inequalities in mortality (ischaemic heart disease is the largest). ${ }^{1}$ Socioeconomic inequalities in smoking need to be closely monitored in order to predict future burdens of lung cancer and other smoking related diseases in relation to socioeconomic status.

Many authors refer to the description of the diffusion of innovations of Rogers, ${ }^{2}$ to understand the diffusion of smoking in populations..$^{3-5}$ The lag in the adoption of smoking between higher and lower socioeconomic groups, and the lag in adoption between men and women, two well established aspects of the diffusion of smoking in western countries, ${ }^{367}$ are both in accordance with the description of Rogers. ${ }^{37}$ These two aspects are both described in the trajectory of the diffusion of smoking that is referred to as "the smoking epidemic". ${ }^{8}$

The smoking epidemic is divided into four stages. In the first stage, prevalence of smoking is low among men and women. In the second stage, the prevalence rises rapidly among men as smoking becomes more and more fashionable, reaching levels of $50-80 \%$. The prevalence among women also rises, typically with a lag of about two decades later than among men. In the third stage the prevalence of smoking has peaked and starts declining among men. After a delay of a few decades it starts declining among women as well. In the fourth stage the prevalence of smoking continues to decline, slowly reaching a stable minimum prevalence level. Because the higher educated are the first to adopt innovations, this trajectory starts earlier among the higher educated than among the lower educated. This means that as the smoking epidemic evolves the lower educated men and women become disadvantaged in terms of smoking prevalence only in the later stages of the epidemic, after the decline of smoking among higher educated men and women has set in.

At present, many northern European countries have reached the fourth stage of the smoking epidemic, which is characterised by persisting or widening socioeconomic differences in smoking, even though overall prevalence of smoking is decreasing. ${ }^{8}$ Socioeconomic inequalities in smoking in southern European countries are found to lag behind those of northern European countries, and southern European countries have mostly reached the third stage of the smoking epidemic. ${ }^{356}$ It is of interest to monitor socioeconomic inequalities in smoking in the south of Europe as well because these inequalities may well be different in magnitude from those experienced before by the northern countries that reached this stage earlier. For example, because of increased awareness of the health effects of smoking and increased policy attention to smoking in Europe, the prevalence of smoking may peak at lower rates among the lower socioeconomic groups in those countries that lag behind in the smoking epidemic. This argument similarly counts for comparing socioeconomic inequalities among women to those among men, because women mostly lag behind men in the smoking epidemic.

Several questions about current (and future) socioeconomic inequalities in smoking in European countries are therefore still open. How will inequalities in smoking evolve among men in countries that have reached the fourth stage of the smoking epidemic? Will inequalities in smoking in southern countries evolve in the same way as in northern countries? Will inequalities in smoking among women evolve in the same way as among men?

By determining socioeconomic inequalities in smoking among several generations of men and women at a given point in time, we can obtain a picture of how inequalities in smoking have evolved in recent years. The purpose of this 
study is to determine the association of socioeconomic status with smoking in several generations of men and women using cross sectional data from 11 European countries at the end of the 1990s.

\section{DATA AND METHODS}

We analysed data from the European Community Household Panel survey (ECHP), which is a social survey designed for the member states of the European Union. The survey used a uniform random sampling design, targeting the national household population of the countries included, and using common blueprint questionnaires. The data were collected by national statistical institutes or research centres. Data checks, weightings and imputations were done centrally by the Statistical Office of the European Communities (Eurostat). Eurostat prepared a user's database from the data of all countries, which included cleaned and encoded data and was ready to use for analyses. For more information about the design of the ECHP we refer to an extensive review of the design and procedures of the ECHP elsewhere. ${ }^{9}$

The data for the current study are from the fifth wave of the survey, in 1998, the first year that smoking data were collected. Countries that were a member state of the European Union in 1998, but did not yet include data on smoking during the fifth wave of the ECHP study, were not included in this study. These countries were France, Luxembourg, and The Netherlands.

Information on response rates is given in table 1 . This table gives the household non-response percentages of the first wave of the survey and of the percentage of persons lost to follow up until the fifth wave. There are large differences between countries in the response rates. The relatively high response rates in Greece and Italy are probably related to the fact that survey participation in these countries is compulsory. The low response rates in Germany reflect mostly a refusal of subjects to participate. ${ }^{9}$ Non-response and attrition would present a problem in our study if they were related to educational level. Some analyses have been performed on attrition in the ECHP, which showed that attrition was only weakly related to educational level. ${ }^{10}$ Surveys from Ireland, Italy, Greece, Spain, Austria, and Portugal tended to lose disproportionately participants with a higher level of education, while the reverse occurred in surveys from Germany, Denmark, Belgium, and the UK.

Level of completed education was used as a measure of socioeconomic status. Three education levels were formed based on the International Standard Classification of Education (ISCED) ${ }^{12}$ : (1) lower secondary education or less; (2) upper secondary education; and (3) tertiary education, which is constituted by higher vocational and university education. The percentage of the population with the lowest level is given in table 2. It should be noted that the percentages of lower educated are relatively high at ages 16-24, because part of this group has not yet finished its education.

Subjects were asked whether they smoked daily, smoked occasionally, used to smoke daily, used to smoke occasionally, or never smoked. No distinction was made between smoking cigarettes, pipes, and cigars. We distinguished between "current daily" smokers and "ever daily" smokers. While inequalities in current smoking express the current situation, inequalities in ever smoking reflects the situation of preceding years. A current smoker was defined as someone who reported smoking daily at the time of the survey. Subjects who reported they used to smoke daily were defined as ever smokers. For Germany and the UK, only data on current smoking were available.

Prevalence rates were age standardised according to the direct method with the population of the European Union and Norway of 1995 as the standard. ${ }^{13}$ Prevalence odds ratios were determined using logistic regression. Participants with upper secondary or tertiary education (groups 2 and 3) were combined and used as the reference category in these analyses. The regression analyses were adjusted for age by including a five year categorical age variable into the model. Analyses were stratified for sex. To test whether odds ratios significantly differed between countries we also performed pooled analyses combining all countries. In these analyses we used the $\chi^{2}$ test to judge if the regression model including an interaction term of country by education was significantly different from the model without such an interaction term. All analyses were performed with the SPSS statistical package. ${ }^{14}$ We identified four age groups: 16-24 years, 2544 years, ages $45-64$ years, and ages $65+$ years. Odds ratios for "ever daily" smoking were only determined for the ages 25 years and over, because in the age group 16-24 years the number of ex-smokers was too small to determine educational inequalities with sufficient precision.

\section{RESULTS}

Table 3 shows the proportion of current smokers and ever smokers for men and women aged 25 years and older for 11 northern and southern European countries. North-south gradients were observed in the prevalence of "current daily" smoking and "ever daily" smoking among women of the ages $45-64$ years and $65+$ years. This gradient was not observed for the ages 25-44 years. Spanish women aged 25-44 years smoked more compared to women from most other countries. Finland was an exception in all age groups, showing relatively low smoking prevalence rates compared

Table 1 Percentages of household non-response at first wave and attrition of interviewed persons until wave 5 (1998) of the ECHP

\begin{tabular}{llccc}
\hline Country & $\begin{array}{l}\text { Household non- } \\
\text { response (first wave) }\end{array}$ & $\begin{array}{l}\text { Acquired number of } \\
\text { interviewed persons }\end{array}$ & $\begin{array}{l}\text { Attrition between } \\
\text { 1994-1998† }\end{array}$ & $\begin{array}{l}\text { Number of persons retained } \\
\text { from the original sample }\end{array}$ \\
\hline Finland & $27 \%$ & 8173 & $10 \%$ & 7381 \\
Denmark & $38 \%$ & 5903 & $29 \%$ & 4187 \\
Ireland & $44 \%$ & 9904 & $36 \%$ & 6324 \\
UK & $28 \%$ & 8915 & $2 \%$ & 8764 \\
Belgium & $16 \%$ & 6710 & $20 \%$ & 5339 \\
Germany & $52 \%$ & 12233 & $5 \%$ & 11562 \\
Austria & $30 \%$ & 7437 & $26 \%$ & 5511 \\
Italy & $9 \%$ & 17729 & $10 \%$ & 15934 \\
Spain & $33 \%$ & 17893 & $23 \%$ & 13779 \\
Portugal & $11 \%$ & 11621 & $2 \%$ & 11412 \\
Greece & $10 \%$ & 12492 & $20 \%$ & 9985 \\
\hline
\end{tabular}

*Source: Eurostat 2000; household response."

†Source: Eurostat 2002; the attrition of interviewed persons. ${ }^{10}$ 
Table 2 Number of subjects for each country and sex (n) and the percentage of the population with a lower level of education (\%)

\begin{tabular}{|c|c|c|c|c|c|c|c|c|}
\hline \multirow[b]{2}{*}{ Country } & \multicolumn{2}{|l|}{$16-24$} & \multicolumn{2}{|c|}{$25-44$} & \multicolumn{2}{|c|}{$45-64$} & \multicolumn{2}{|l|}{$65+$} \\
\hline & $\mathbf{n}$ & $\%$ & n & $\%$ & n & $\%$ & n & $\%$ \\
\hline \multicolumn{9}{|l|}{ Men } \\
\hline Finland & 600 & (38) & 1313 & (18) & 1308 & (41) & 438 & (61) \\
\hline Denmark & 242 & $(45)$ & 842 & (16) & 641 & (20) & 310 & (43) \\
\hline Ireland & 625 & (34) & 1092 & (40) & 902 & (57) & 510 & (76) \\
\hline UK & 588 & (32) & 1667 & (25) & 1159 & (34) & 655 & (54) \\
\hline Belgium & 307 & (41) & 1012 & (21) & 741 & (33) & 430 & (54) \\
\hline Germany & 738 & (64) & 2413 & (16) & 1771 & (19) & 653 & (15) \\
\hline Austria & 521 & (61) & 1166 & (10) & 936 & (22) & 516 & (40) \\
\hline Italy & 1134 & (48) & 3063 & (44) & 2380 & (65) & 1199 & (84) \\
\hline Spain & 1234 & (47) & 2454 & (48) & 1714 & (73) & 1238 & (88) \\
\hline Portugal & 961 & (74) & 1851 & (78) & 1505 & (90) & 1108 & (95) \\
\hline Greece & 698 & (29) & 1592 & (37) & 1473 & (67) & 994 & (85) \\
\hline \multicolumn{9}{|l|}{ Women } \\
\hline Finland & 605 & (37) & 1320 & (13) & 1306 & (41) & 491 & (68) \\
\hline Denmark & 276 & (37) & 848 & (13) & 665 & (31) & 363 & (69) \\
\hline Ireland & 597 & (26) & 1108 & (35) & 935 & (58) & 555 & (77) \\
\hline UK & 671 & (29) & 1856 & (27) & 1366 & (45) & 906 & (69) \\
\hline Belgium & 330 & (33) & 1142 & (21) & 793 & (43) & 584 & (65) \\
\hline Germany & 742 & (57) & 2512 & (18) & 1791 & (32) & 942 & (49) \\
\hline Austria & 508 & (62) & 1189 & (23) & 1011 & (43) & 694 & (70) \\
\hline Italy & 1154 & $(40)$ & 3094 & (40) & 2377 & (74) & 1533 & (92) \\
\hline Spain & 1164 & (36) & 2440 & (47) & 1862 & (83) & 1673 & (94) \\
\hline Portugal & 935 & (65) & 1800 & (71) & 1783 & (90) & 1469 & (98) \\
\hline Greece & 739 & $(25)$ & 1670 & (39) & 1526 & (79) & 1293 & (93) \\
\hline
\end{tabular}

to other northern countries. Among men, similar northsouth gradients as among women were neither observed for "current" nor for "ever daily" smoking. Spain and Greece ranked among the countries with the highest "current daily" smoking prevalences in all age groups.

Figure 1 shows the geographical pattern of educational inequalities in "current daily" smoking for women aged 25 years and older. Odds ratios with values significantly higher than 1 imply a higher smoking prevalence in lower educational groups. A geographical pattern was observed, with inequalities for all three age groups being larger in the northern countries than in the southern countries. Odds ratios $>1$ were not observed in any of the age groups for Austria and the southern European countries. In contrast,

Table 3 Age standardised proportions of "current daily" smoking and "ever daily" smoking for women and men, of all education levels

\begin{tabular}{|c|c|c|c|c|c|c|c|c|c|}
\hline \multirow[b]{2}{*}{ Country } & & \multicolumn{4}{|l|}{ Women } & \multicolumn{4}{|l|}{ Men } \\
\hline & & $25-44$ & $45-64$ & $65+$ & All 25+ & $25-44$ & $45-64$ & $65+$ & All 25+ \\
\hline Finland & $\begin{array}{l}\text { Current } \\
\text { Ever }\end{array}$ & $\begin{array}{l}0.21 \\
0.36\end{array}$ & $\begin{array}{l}0.14 \\
0.26\end{array}$ & $\begin{array}{l}0.03 \\
0.10\end{array}$ & $\begin{array}{l}0.15 \\
0.27\end{array}$ & $\begin{array}{l}0.32 \\
0.49\end{array}$ & $\begin{array}{l}0.24 \\
0.53\end{array}$ & $\begin{array}{l}0.10 \\
0.57\end{array}$ & $\begin{array}{l}0.25 \\
0.53\end{array}$ \\
\hline Denmark & $\begin{array}{l}\text { Current } \\
\text { Ever }\end{array}$ & $\begin{array}{l}0.39 \\
0.54\end{array}$ & $\begin{array}{l}0.36 \\
0.56\end{array}$ & $\begin{array}{l}0.26 \\
0.49\end{array}$ & $\begin{array}{l}0.36 \\
0.55\end{array}$ & $\begin{array}{l}0.37 \\
0.51\end{array}$ & $\begin{array}{l}0.43 \\
0.67\end{array}$ & $\begin{array}{l}0.32 \\
0.74\end{array}$ & $\begin{array}{l}0.39 \\
0.63\end{array}$ \\
\hline Ireland & $\begin{array}{l}\text { Current } \\
\text { Ever }\end{array}$ & $\begin{array}{l}0.30 \\
0.40\end{array}$ & $\begin{array}{l}0.23 \\
0.36\end{array}$ & $\begin{array}{l}0.15 \\
0.29\end{array}$ & $\begin{array}{l}0.25 \\
0.37\end{array}$ & $\begin{array}{l}0.33 \\
0.45\end{array}$ & $\begin{array}{l}0.24 \\
0.47\end{array}$ & $\begin{array}{l}0.22 \\
0.57\end{array}$ & $\begin{array}{l}0.28 \\
0.49\end{array}$ \\
\hline UK & Current & 0.30 & 0.26 & 0.15 & 0.26 & 0.32 & 0.26 & 0.14 & 0.26 \\
\hline Belgium & $\begin{array}{l}\text { Current } \\
\text { Ever }\end{array}$ & $\begin{array}{l}0.26 \\
0.38\end{array}$ & $\begin{array}{l}0.22 \\
0.35\end{array}$ & $\begin{array}{l}0.08 \\
0.17\end{array}$ & $\begin{array}{l}0.21 \\
0.33\end{array}$ & $\begin{array}{l}0.36 \\
0.46\end{array}$ & $\begin{array}{l}0.32 \\
0.62\end{array}$ & $\begin{array}{l}0.20 \\
0.67\end{array}$ & $\begin{array}{l}0.32 \\
0.57\end{array}$ \\
\hline Germany & Current & 0.30 & 0.18 & 0.07 & 0.21 & 0.45 & 0.33 & 0.13 & 0.34 \\
\hline Austria & $\begin{array}{l}\text { Current } \\
\text { Ever }\end{array}$ & $\begin{array}{l}0.25 \\
0.32\end{array}$ & $\begin{array}{l}0.15 \\
0.22\end{array}$ & $\begin{array}{l}0.03 \\
0.07\end{array}$ & $\begin{array}{l}0.17 \\
0.24\end{array}$ & $\begin{array}{l}0.36 \\
0.46\end{array}$ & $\begin{array}{l}0.27 \\
0.48\end{array}$ & $\begin{array}{l}0.13 \\
0.43\end{array}$ & $\begin{array}{l}0.29 \\
0.47\end{array}$ \\
\hline Italy & $\begin{array}{l}\text { Current } \\
\text { Ever }\end{array}$ & $\begin{array}{l}0.18 \\
0.22\end{array}$ & $\begin{array}{l}0.16 \\
0.18\end{array}$ & $\begin{array}{l}0.04 \\
0.06\end{array}$ & $\begin{array}{l}0.15 \\
0.18\end{array}$ & $\begin{array}{l}0.36 \\
0.42\end{array}$ & $\begin{array}{l}0.35 \\
0.50\end{array}$ & $\begin{array}{l}0.15 \\
0.41\end{array}$ & $\begin{array}{l}0.32 \\
0.45\end{array}$ \\
\hline Spain & $\begin{array}{l}\text { Current } \\
\text { Ever }\end{array}$ & $\begin{array}{l}0.39 \\
0.49\end{array}$ & $\begin{array}{l}0.12 \\
0.17\end{array}$ & $\begin{array}{l}0.01 \\
0.03\end{array}$ & $\begin{array}{l}0.22 \\
0.28\end{array}$ & $\begin{array}{l}0.50 \\
0.62\end{array}$ & $\begin{array}{l}0.39 \\
0.62\end{array}$ & $\begin{array}{l}0.22 \\
0.59\end{array}$ & $\begin{array}{l}0.41 \\
0.63\end{array}$ \\
\hline Portugal & $\begin{array}{l}\text { Current } \\
\text { Ever }\end{array}$ & $\begin{array}{l}0.12 \\
0.16\end{array}$ & $\begin{array}{l}0.03 \\
0.04\end{array}$ & $\begin{array}{l}0.00 \\
0.01\end{array}$ & $\begin{array}{l}0.07 \\
0.09\end{array}$ & $\begin{array}{l}0.42 \\
0.51\end{array}$ & $\begin{array}{l}0.29 \\
0.48\end{array}$ & $\begin{array}{l}0.13 \\
0.43\end{array}$ & $\begin{array}{l}0.32 \\
0.49\end{array}$ \\
\hline Greece & $\begin{array}{l}\text { Current } \\
\text { Ever }\end{array}$ & $\begin{array}{l}0.27 \\
0.29\end{array}$ & $\begin{array}{l}0.13 \\
0.14\end{array}$ & $\begin{array}{l}0.02 \\
0.04\end{array}$ & $\begin{array}{l}0.17 \\
0.19\end{array}$ & $\begin{array}{l}0.59 \\
0.64\end{array}$ & $\begin{array}{l}0.48 \\
0.58\end{array}$ & $\begin{array}{l}0.21 \\
0.40\end{array}$ & $\begin{array}{l}0.48 \\
0.58\end{array}$ \\
\hline All countries* & $\begin{array}{l}\text { Current } \\
\text { Ever }\end{array}$ & $\begin{array}{l}0.28 \\
0.38\end{array}$ & $\begin{array}{l}0.20 \\
0.31\end{array}$ & $\begin{array}{l}0.10 \\
0.19\end{array}$ & $\begin{array}{l}0.22 \\
0.32\end{array}$ & $\begin{array}{l}0.38 \\
0.50\end{array}$ & $\begin{array}{l}0.33 \\
0.56\end{array}$ & $\begin{array}{l}0.19 \\
0.57\end{array}$ & $\begin{array}{l}0.33 \\
0.55\end{array}$ \\
\hline
\end{tabular}

*All countries "Current" includes all countries; "Ever", UK and Germany are excluded. The prevalence estimates for all countries are adjusted for the size of the samples of individual countries. 


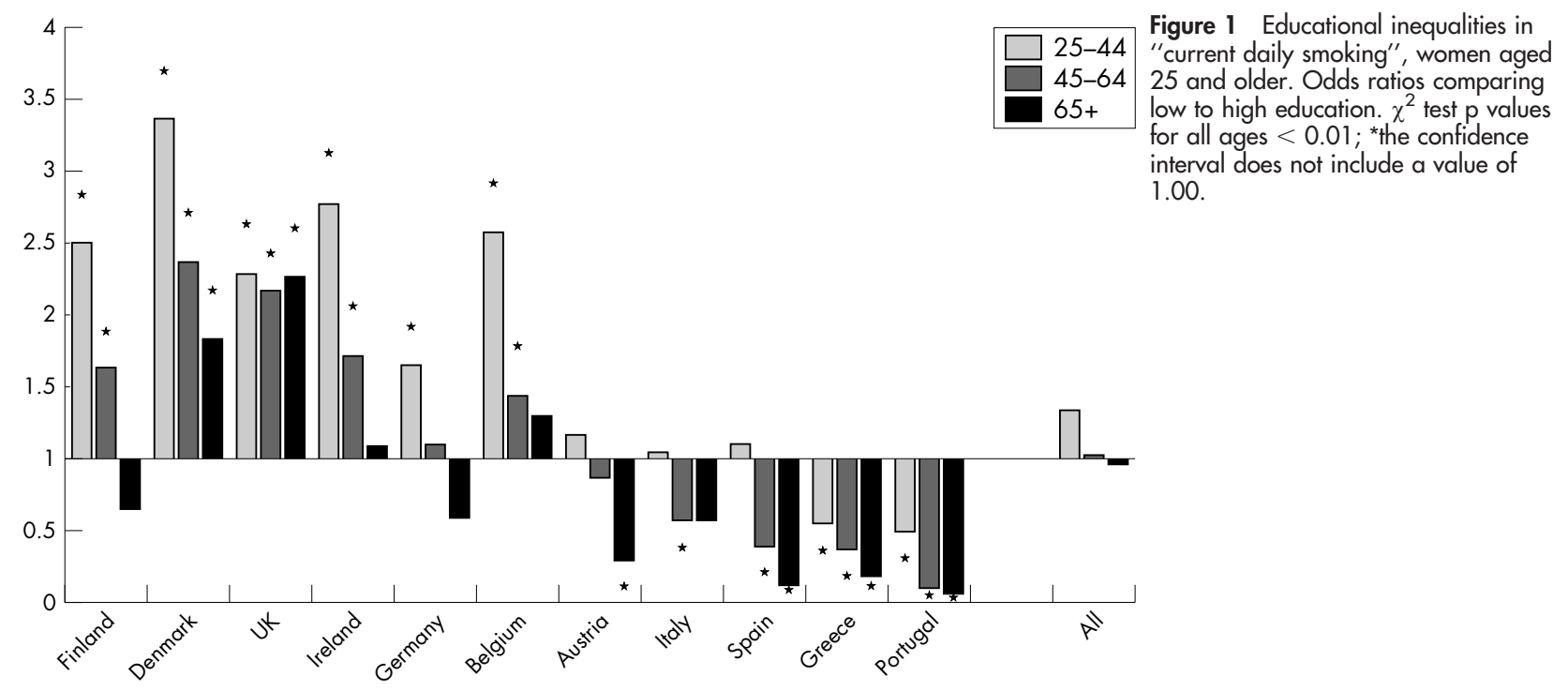

inequalities were observed for Denmark, the UK, and Belgium in all of the age groups, for Finland and Ireland in the age groups younger than age 65 , and for Germany in the youngest adults only.

Figure 2 shows the geographical pattern of educational inequalities for "ever daily" smoking for women aged 25 years and over. A north-south pattern of educational inequalities was also observed for "ever daily" smoking. There were no odds ratios $>1$ for women from Italy, Spain, Greece, and Portugal. Instead, smoking was more common among the higher educated in these countries, especially in Greece and Portugal. The odds ratios for all ages in these countries had values significantly $<1$. In the northern countries, most odds ratios were $>1$. Inequalities were observed in Finland in the age groups younger than 65 years, and in Denmark, Ireland, and Belgium among the youngest adults only.

The geographical pattern of inequalities in "current daily" smoking for men is shown in fig 3. Ireland and the UK showed inequalities in all generations. Finland, Denmark, Germany, Belgium, and Spain showed inequalities among men aged $45-59$ years and younger. The other countries only showed inequalities among young adults (ages $25-44$ years). A $p$ value of 0.06 of the $\chi^{2}$ test for the young adults indicated that differences between countries in the association of smoking and education could not be determined with statistical significance (at the 95\% level). North-south patterns in the magnitude of inequalities were not observed. However, among men older than 44 years, significant inequalities were observed more often in northern European countries as compared to southern European countries.

The results for "ever daily" smoking for men are shown in fig 4. Inequalities in "ever daily" smoking were observed in Ireland in all generations (although not significantly among ages 45-64 years), in Finland, Belgium, and Spain in the age groups 45-64 years and younger, and in Denmark, Austria, Italy, Greece, and Portugal in the age group 25-44 years. Negative associations of "ever daily" smoking with education occurred earlier (that is, in older age groups) among men than among women.

For the age group 16-24 years the prevalence rates and odds ratios for "current daily" smoking are given in table 4 . Prevalence of "current daily" smoking among women was

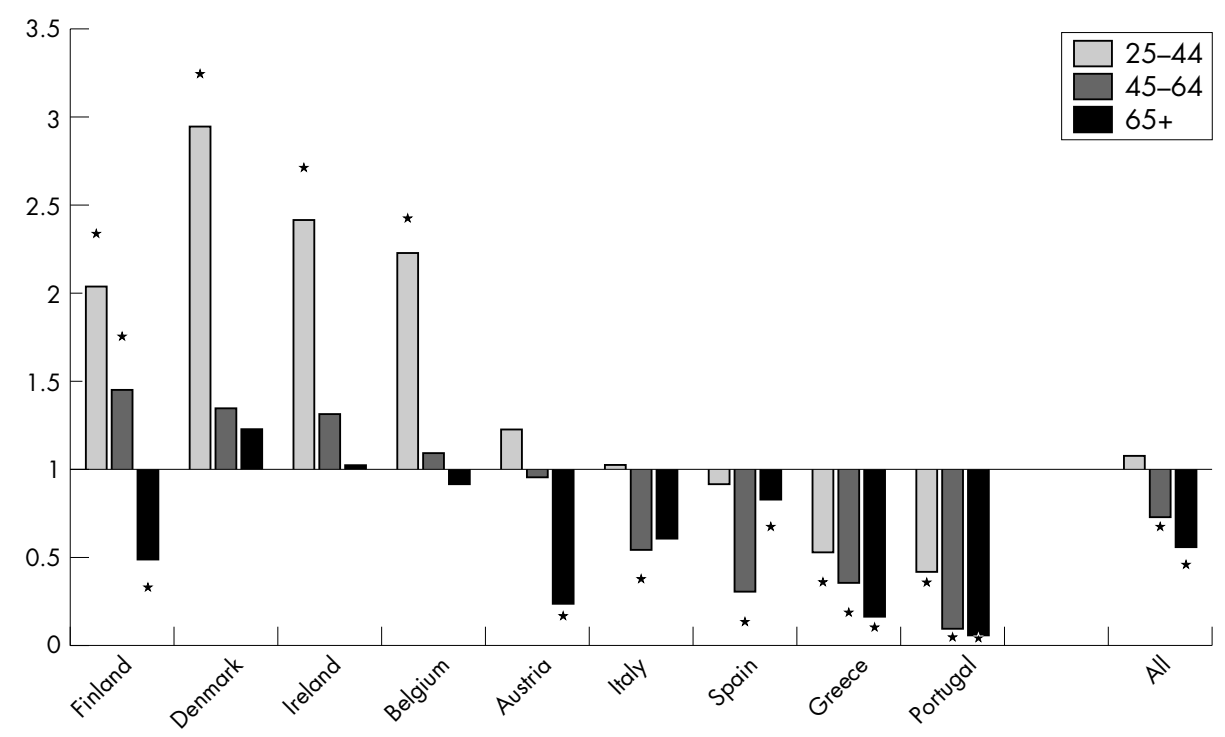

Figure 2 Educational inequalities in "ever daily smoking", women aged 25 and older. Odds ratios comparing low to high education. $\chi^{2}$ test $p$ values for all ages $<0.01$; ${ }^{*}$ the confidence interval does not include a value of 1.00 . 


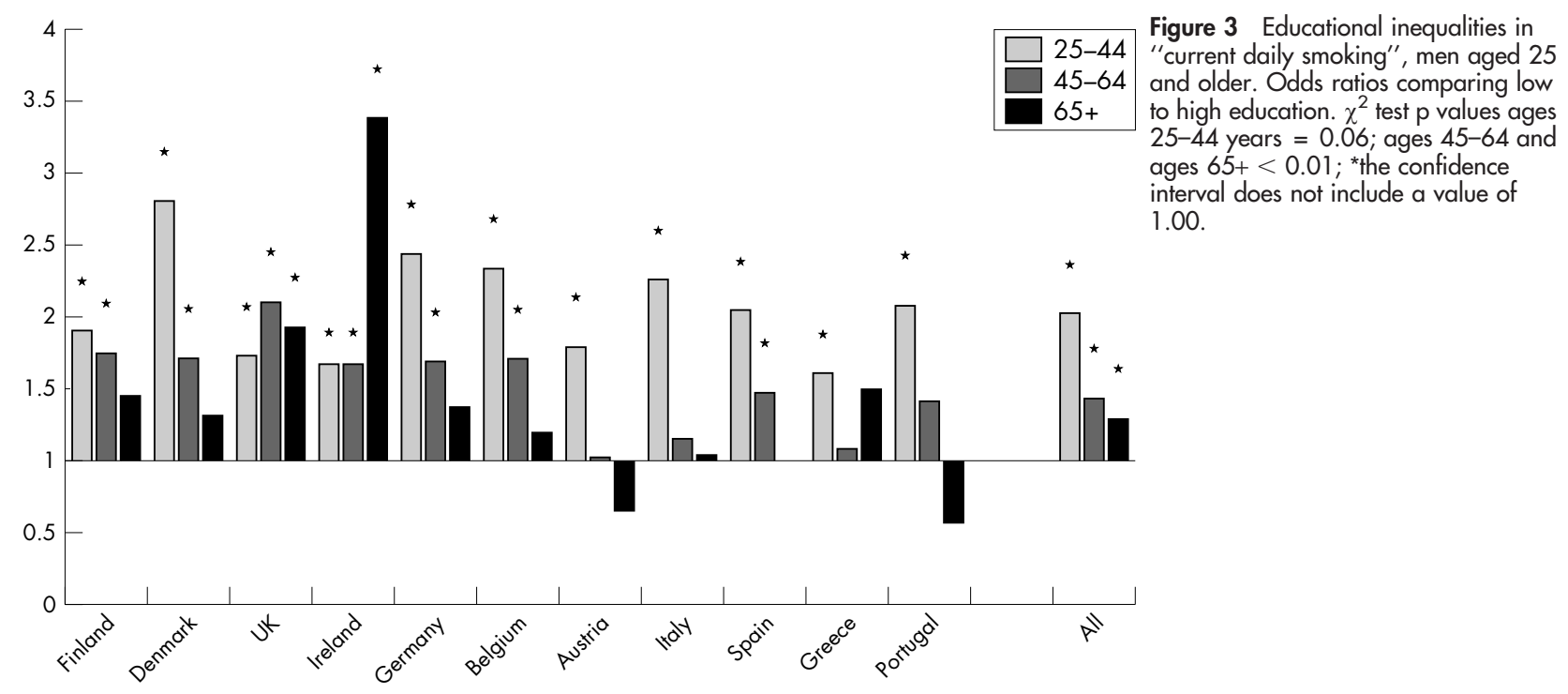

relatively high in the UK and Spain, followed by Denmark, Ireland, Germany, and Belgium. The prevalence among women was relatively low in Portugal and Italy. Among men of this age group, the prevalence was highest in Austria and the UK, but differences between countries in the prevalence of "current daily" smoking among men were not large.

With regard to educational inequalities in "current daily" smoking among women of 16-24 years, countries can be divided into three groups. In the first group, comprising Finland and the UK, odds ratios were relatively large and significant. In the second group, comprising Denmark, Ireland, Germany, Belgium, Austria, Italy, and Spain, the odds ratios also indicated a disadvantage for the lower educated in terms of smoking, but odds ratios were smaller and not significant. In the third group, comprising Greece and Portugal, the odds ratios were $<1$, indicating that the higher educated smoke more. Among men of this age group, the lower educated smoked more in all countries. These inequalities were relatively large and significant in the UK, Belgium, and the southern European countries.

\section{DISCUSSION}

This study focused on geographical variations in educational inequalities in the prevalence of "current daily" smoking and "ever daily" smoking. We identified countries and age groups where educational inequalities in smoking (more among lower groups) had emerged by 1998. We observed a northsouth gradient among women older than 24 years, with higher smoking prevalences and stronger negative associations of education with smoking in the northern countries. For men we did not observe such a geographical pattern. A higher prevalence of smoking among the lower educated occurred later among women than among men (that is, in younger age groups). This would be expected based on the smoking epidemic model and the diffusion of innovations theory. A higher prevalence of smoking among the lower educated in the youngest age group (16-24 years) was found for all countries, with the exception of women from Greece and Portugal.

Some limitations of the study need to be discussed. One limitation is the use of self reported data on smoking, which may result in underreporting of smoking, especially among

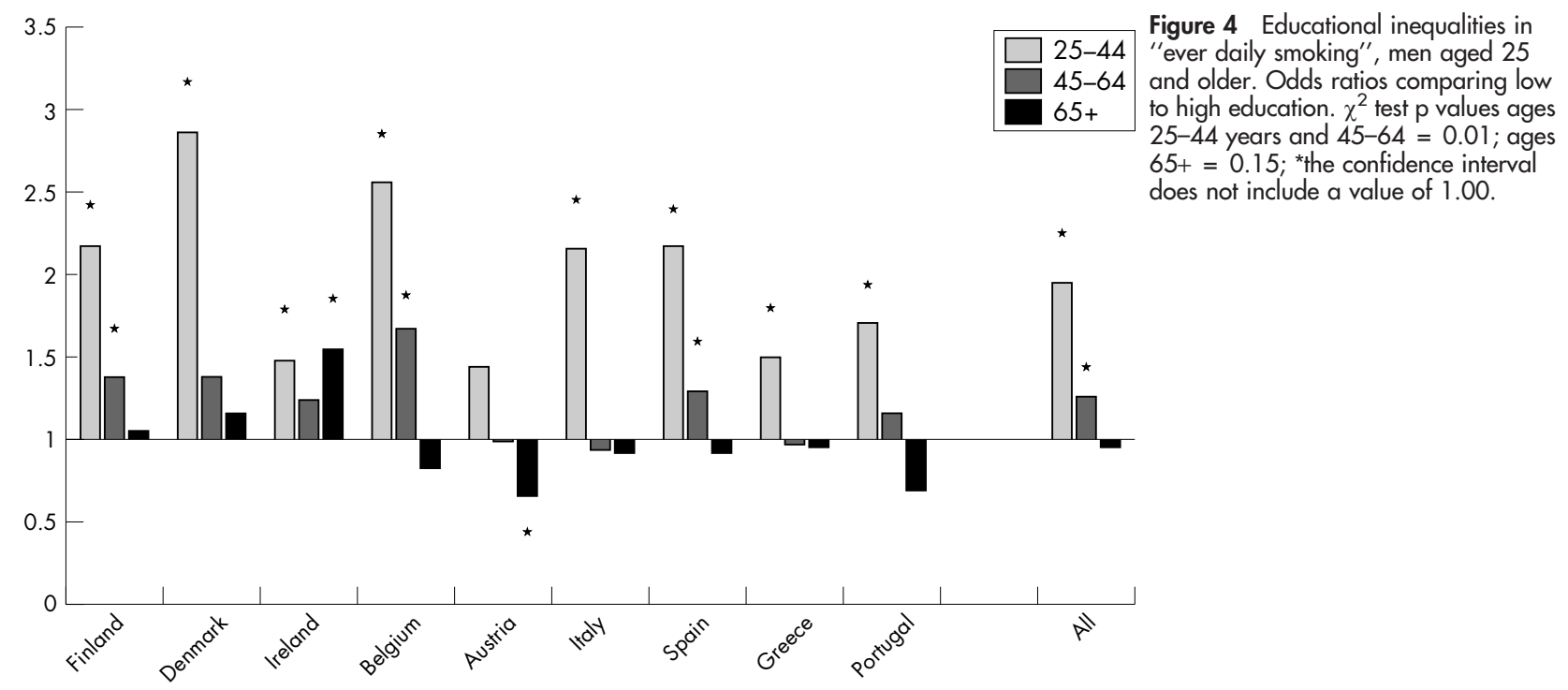


Table 4 Prevalence of "current daily" smoking and educational inequalities in "current daily" smoking; women and men aged $16-24$ years

\begin{tabular}{|c|c|c|c|c|c|c|c|c|}
\hline \multirow[b]{2}{*}{ Country } & \multicolumn{4}{|l|}{ Women } & \multicolumn{4}{|l|}{ Men } \\
\hline & Low & High & OR & $95 \% \mathrm{Cl}$ & Low & High & OR & $95 \% \mathrm{Cl}$ \\
\hline Finland & 0.30 & 0.16 & 1.87 & 1.09 to 3.22 & 0.37 & 0.28 & 1.32 & 0.84 to 2.07 \\
\hline Denmark & 0.31 & 0.30 & 1.33 & 0.64 to 2.74 & 0.31 & 0.20 & 1.77 & 0.91 to 3.44 \\
\hline UK & 0.41 & 0.27 & 1.91 & 1.29 to 2.82 & 0.48 & 0.30 & 2.16 & 1.45 to 3.22 \\
\hline Ireland & 0.35 & 0.24 & 1.43 & 0.91 to 2.23 & 0.28 & 0.24 & 1.20 & 0.79 to 1.83 \\
\hline Germany & 0.27 & 0.29 & 1.20 & 0.80 to 1.81 & 0.35 & 0.52 & 1.18 & 0.80 to 1.74 \\
\hline Belgium & 0.29 & 0.22 & 1.41 & 0.74 to 2.67 & 0.48 & 0.20 & 3.05 & 1.65 to 5.63 \\
\hline Austria & 0.25 & 0.20 & 1.49 & 0.87 to 2.54 & 0.40 & 0.60 & 1.06 & 0.67 to 1.68 \\
\hline Italy & 0.12 & 0.09 & 1.39 & 0.92 to 2.12 & 0.34 & 0.21 & 2.35 & 1.76 to 3.15 \\
\hline Spain & 0.32 & 0.27 & 1.26 & 0.95 to 1.67 & 0.40 & 0.25 & 2.32 & 1.77 to 3.04 \\
\hline Greece & 0.13 & 0.17 & 0.76 & 0.46 to 1.26 & 0.39 & 0.29 & 1.72 & 1.15 to 2.58 \\
\hline Portugal & 0.07 & 0.08 & 0.80 & 0.48 to 1.33 & 0.29 & 0.19 & 2.00 & 1.39 to 2.87 \\
\hline All countries & 0.27 & 0.23 & 1.36 & 1.19 to 1.55 & 0.37 & 0.32 & 1.85 & 1.65 to 2.08 \\
\hline Interaction country* education & $p=0.04$ & & & & $p=0.01$ & & & \\
\hline
\end{tabular}

OR, odds ratio; $95 \% \mathrm{Cl}, 95 \%$ confidence interval; the prevalence estimates for all countries are adjusted for the size of the samples of the individual countries.

the youngest ages. If under-reporting of smoking is differentiated by educational status, the patterns that were found in this study may be biased. Some studies have investigated under-reporting in relation to education in different countries and have shown inconsistent results. ${ }^{15-17}$ A review study on self reporting of smoking behaviour concluded that self reports of smoking were quite accurate. ${ }^{18}$ Still, we cannot exclude the possibility that under-reporting did occur and that it was differentiated according to education. However, we do not think it likely that the geographical patterns, especially the north-south patterns, can be explained by under-reporting only.

Non-response rates are high in some of the countries. There is no information on the association of baseline nonresponse with education in the ECHP. We cannot exclude the possibility that response bias has influenced our results. However, we would like to stress that our key results conform to a remarkable degree to the predicted trajectory of the smoking epidemic diffusion model, with inequalities in smoking occurring sooner among men and sooner in northern European countries. In addition, our results are to a large extent in agreement with the findings of studies using national survey data. Therefore, we do not think that selection bias can explain the geographical gradient that is observed in our study.

Another limitation relates to the use of level of education as an indicator of socioeconomic status. The distributions of level of education within the populations of some countries were rather skewed. For example, in Italy, Spain, Portugal, and Greece a large proportion of the older, and especially female, populations had a low level of education. Furthermore, education is implicitly skewed towards lower levels in the youngest age group, since a large part of this group has not yet completed their highest level of education. Although these large groups of lower educated are homogeneous in terms of education, variations in terms of income or other socioeconomic indicators may exist within these groups. However, in a forthcoming study on the same data we already reported that income inequalities in smoking almost disappeared after adjustment for education, indicating that education is a stronger predictor of smoking in these countries than income is. ${ }^{19}$

The results of this study are comparable with the results of another international study that described differences between countries around 1990, ${ }^{6}$ which were obtained from data of national surveys. Their study reported similar northsouth gradients for middle aged and older women as we did. However, their study also reported a weak gradient for older men, which we did not observe. In addition, their study reported a stronger association between high education and smoking for women from Spain and Portugal. These differences may be due to the 10 year difference between the data and may reflect changing inequalities in smoking during the 1990s, with less favourable trends among the lower educated. Both the former international study and our study show results that conform remarkably to the smoking epidemic diffusion model and fit with what would be expected on the basis of it. This is the case for the apparent lag time in socioeconomic inequalities in smoking between northern and southern European countries, and also for the lag between women and men in these European countries. These results indicate that men and women in Europe pass through the same basic trends as the smoking epidemic evolves, and similarly experience socioeconomic inequalities in smoking.

Our results for Spain are in agreement with those of a national study which found that initiation of smoking was higher among higher educated than among lower educated men born from 1924 to 1942, but that this association was reversed among men born from 1944 to $1962 .{ }^{20}$ We observed, for the year 1998, that education and smoking were positively related among men aged 65 years and older (born before 1933), but that they were inversely related among men aged 45-64 years of age (born 1934 to 1953). For Italy, higher smoking prevalence was observed among lower educated adult men (aged 25-74 years), and among higher educated adult women in the year $1994 .^{21}$ These findings are in agreement with our findings, although the broad age range used in the Italian study does not allow for a more detailed comparison of specific generations. Compared to the results of a study on smoking in Portugal in 1999-2000 and variations in smoking by education, we observed similar patterns of smoking by education and sex-that is, men had a higher prevalence of smoking than women, and among women the higher educated smoked more. ${ }^{22}$

We are among the first to report on socioeconomic inequalities in smoking in countries such as Austria, Belgium, and Greece. Data from these countries strengthened the finding of the north-south gradient in the magnitude of socioeconomic inequalities in smoking. The smoking epidemic was the least evolved in Portugal and Greece. These countries still showed higher smoking prevalence among the higher educated women as compared to the lower educated of all age groups. Austria showed a more southern European pattern, as the reversal of inequalities in this country occurred among men and women only among young adults. The results for Belgium were more alike those of northern European countries, such as Denmark and the UK, as the 
reversal of inequalities had occurred in all generations of Belgian women.

The inclusion of the age group 16-24 years was an important element of the study. We have discussed the results for these ages separately because we expect that the limitations mentioned above (the use of self reported data, and education as an indicator of socioeconomic status) apply especially to this age group. Nonetheless, some important patterns were observed. Among women in Italy and Spain, smoking was already more prevalent among lower educated women. The large inequalities in smoking among men aged 16-24 years from most countries should warn us that among men, a reduction in smoking inequalities might not be expected to occur automatically in the near future.

This study is the first to accurately show in which age groups the reversal of inequalities in smoking has occurred in several European countries. Our findings may be used to predict educational inequalities in lung cancer two to three decades after the end of the 1990s, and inequalities in chronic obstructive pulmonary disease somewhat later than that. For example, they imply a continuation of the educational inequalities in lung cancer that are observed among men in many European countries, and among women in the north, ${ }^{23}$ and perhaps an emergence of inequalities in lung cancer among women in the south later.

Tobacco control policies should focus more on the lower educated groups specifically instead of only on national populations at large. Despite differences between countries and men and women in timing and magnitude of the smoking epidemic among different generations, men and women of most countries show the same basic trends as they pass through the smoking epidemic. Such a fact should stress the importance, and the opportunities, of international cooperation in reducing inequalities in smoking by designing appropriate tobacco control measures and learning from other countries' experiences with reducing inequalities in smoking.

There is considerable potential to develop comprehensive strategies aimed at reducing tobacco consumption among lower socioeconomic groups. Even though this potential is not being seized upon as yet, many tobacco control measures may work to reduce overall smoking prevalence and at the same time achieve the largest reductions among lower socioeconomic groups. ${ }^{24}$ This applies to price policies, but may also apply to other measures if they are targeted to lower socioeconomic groups and tailored towards their needs. For

\section{What this paper adds}

Studies have shown that the distribution of the smoking epidemic in Europe is geographically patterned. The epidemic is further advanced in northern European countries than in southern European countries. There is also evidence that this north-south gradient applies to socioeconomic inequalities in smoking.

We accurately identified those generations of women and men in which a negative association of education with smoking had emerged in 1998 for several European countries. Our international overview is among the first to include data from Austria, Belgium, Portugal, and Greece. We showed that a north-south gradient still prevails among women older than 24 years in 1998. For men such a gradient was not observed, as the magnitude of inequalities in smoking was similar everywhere. We found a negative association of education with smoking among men and women aged 16-24 years from all countries, with the exception of young women from Greece and Portugal. example, removal of financial barriers is a key element for the provision of smoking cessation services to poor people. ${ }^{25}$ Similarly, a greater enforcement of supply based measures such as age restrictions on tobacco purchase can have greater effects in poor neighbourhoods, where such restrictions are often enforced less strictly. In addition, geographic targeting may be useful, such as the provision of services or interventions in deprived neighbourhoods. Mass media and public education approaches may achieve greater effects among lower socioeconomic groups by tailoring their messages, materials, and channels according to the needs of these groups.

Finally, marketing strategies of tobacco companies play a significant role in the diffusion of smoking. ${ }^{26}$ For example, tobacco marketing is taking advantage of the changing roles of women in southern European countries by creating images that link smoking among women with emancipation. ${ }^{27}$ If such marketing strategies are allowed to continue, they will have a large impact on the future prevalence of smoking in these populations, including that of the most disadvantaged. A total ban on tobacco advertisement and promotion may therefore be a necessary step to prevent socioeconomic inequalities in smoking, and smoking related disease.

\section{ACKNOWLEDGEMENTS}

Financial support for this study comes from the project "SocioEconomic determinants of Healthy Ageing" (SEdHA), which is subsidised as part of the Fifth Framework Programme on "Quality of Life and Management of Living Resources" of the European Commission (contract QLK6-CT-1999-02161). This paper is also supported by the project "Tackling socioeconomic inequalities smoking in Europe" which is financed by the European Commission (SANCO) through the European Network on Smoking Prevention (ENSP). The authors thank Tanja Houweling for valuable comments on an earlier draft of this paper.

\section{Authors' affiliations}

M Huisman, A E Kunst, J P Mackenbach, Department of Public Health, Erasmus MC, University Medical Center Rotterdam, Rotterdam, The Netherlands

Competing interests: none

\section{REFERENCES}

1 Huisman $M$, Kunst $A E$, Bopp $M$, et al. Socioeconomic inequalities in causespecific mortality: a study of middle-aged and older men and women in 8 Western European populations. Lancet (in press).

2 Rogers, EM. Diffusion of innovations. New York: Free Press, 1995.

3 Graham H. Smoking prevalence among women in the European Community 1950-1990. Soc Sci Med 1996;43:243-54.

4 Borras JM, Fernandez E, Schiaffino A, et al. Pattern of smoking initiation in Catalonia, Spain, from 1948 to 1992. Am J Public Health 2000;90:1459-62.

5 Pampel FC. Age and education patterns of smoking among women in highincome nations. Soc Sci Med 2003;57:1505-14.

6 Cavelaars AEJM, Kunst AE, Geurts JJ, et al. Educational differences in smoking: International comparisons. BMJ 2000;320:1102-7.

7 Waldron I. Patterns and causes of gender differences in smoking. Soc Sci Med 1991;32:989-1005.

8 Lopez AD, Collishaw NE, Piha T. A descriptive model of the cigarette epidemic in developed countries. Tobacco Control 1994;3:242-7.

9 Peracchi F. The European Community Household Panel: a review. Emp Econ 2002;27:63-90.

10 Eurostat. Sample attrition between waves 1 and 4 in the European Community Household Panel. Eurostat: Luxembourg, 2002 (Doc PAN 185/02).

11 Eurostat. ECHP data quality. Eurostat: Luxembourg, 2000 (Doc PAN 108/00 Revised).

12 UNESCO. International Standard Classification of Education 1997. UNESCO: Paris, 1997.

13 Eurostat. Demographic Statistics 1997. Eurostat: Luxembourg, 1997.

14 SPSS Inc. SPSS for Windows; release 11.0.1. Chicago: SPSS Inc, 2001.

15 Suadicani P, Hein HO, Gyntelberg F. Serum validated tobacco use and social inequalities in risk of ischaemic heart disease. Intern J Epidemiol 1994;23:293-300.

16 Wagenknecht LE, Burke GL, Perkins LL, et al. Misclassification of smoking status in the CARDIA study: a comparison of self-report with serum cotinine levels. Am J Public Health 1992;82:33-6. 
17 Van Loon AJ, Tijhuis M, Picavet HS, et al. Survey non-response in the Netherlands: effects on prevalence estimates and associations. Ann Epidemiol 2003;13:105-10

18 Patrick D, Cheadle A, Thompson D, et al. The validity of self-reported smoking: a review and meta-analysis. Am J Public Health 1994;84:1086-93.

19 Huisman M, Kunst AE, Mackenbach JP. Inequalities in the prevalence of smoking in the European Union: comparing education and income. Prev Med (in press).

20 Schiaffino A, Fernandez E, Borrell C, et al. Gender and educational differences in smoking initiation rates in Spain from 1948 to 1992. Eur J Public Health 2003; 13:56-60.

21 Faggiano F, Versino E, Lemma P. Decennial trends of social differentials in smoking habits in Italy. Cancer Causes Control 2001;12:665-71.
22 Santos A-C, Barros H. Smoking patterns in a community sample of Portuguese adults, 1999-2000. Prev Med 2004;38:114-9.

23 Mackenbach J, Huisman $M$, Andersen $O$, et al. Inequalities in lung cancer mortality by the educational level in 10 European populations. Eur J Cancer 2004;40:126-35.

24 Platt S, Amos A, Gnich W, et al. Smoking policies. In: Mackenbach JP, Bakker MJ, eds. Reducing inequalities in health: a European perspective. London: Routledge, 2002.

25 Marsh A. McKay S. Poor smokers. London: Policy Studies Institute 1994.

26 Zimbardo PG, Leippe MR. The psychology of attitude change and social influence. New York: McGraw-Hill, Inc, 1991.

27 Amos A, Haglund M. From social taboo to "torch of freedom": the marketing of cigarettes to women. Tobacco Control 2000;9:3-8.

The Lighter Side
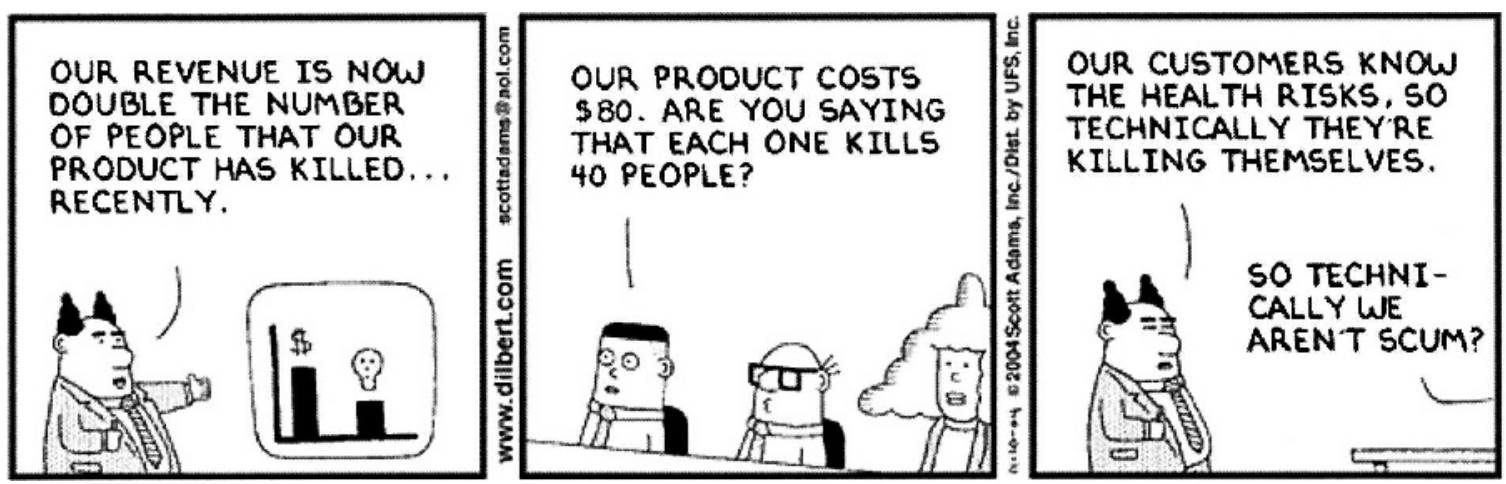

Dilbert, by Scott Adams. (C) United Media. 